\title{
POŠTA
}

TELEKOMUNIKÁCIE A

ELEKTRONICKY OBCHOD

Qीelp

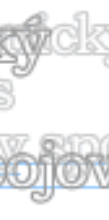

\section{EKONOMICKÁ REGULÁCIA LETÍSK V EURÓPE A VO SVETE, VČERA A DNES}

\author{
Alena Novák Sedláčková*
}

\section{Ekonomická regulácia letísk}

Ekonomická regulácia predstavuje svoju vlastnú deformáciu a na konci je kompromis vytvorený medzi nedokonalou konkurenciou a nedokonalou reguláciou. Rovnováha medzi dvoma nedokonalost'ami sa môže menit' a znovu by sa mala otvárat' otázka ekonomickej regulácie. Ked’ letiská využívajú svoju trhovú silu, potom ich pasívne ekonomické náklady môžu byt' menšie. Je potrebné vytvorit' rovnováhu medzi ekonomickými efektmi trhovej sily a potenciálnou potrebou regulačného zásahu. ${ }^{1}$ Európska Komisia roky podnikala rôzne kroky na zvýšenie konkurencie medzi letiskami. Letiská ju zabezpečovali pomocou: limitácie počtu vol'ných slotov na najdôležitejších letiskách a posilnením pozície letísk, ktoré v konkurenčnom prostredí boli schopné prežit'.

Niektoré kroky Európskej Komisie majú za ciel' ul'ahčit' prístup ku preplneným letiskám, iné zabezpečia rovnaké zachádzanie s leteckými spoločnost’ami a nakoniec sa venujú aj vyhl'adávaniu konkurenčných tlakov na zníženie cien a zdokonalenie služieb, ktoré letiská ponúkajú. ${ }^{2}$

Nie všetky krajiny a letiská súhlasia s ekonomickou reguláciou letísk a uplatňujú ju. Na základe nižšie uvedenej tabul'ky názorne poukazujeme na súčasnú situáciu, ktorá je na trhu letísk v EÚ, kedy nadpolovičná väčšina štátov uplatňuje aspoň na jednom svojom letisku ekonomickú reguláciu letiskových poplatkov.

Tabul'ka 1: Uplatňovanie ekonomickej regulácie letísk v Európe a vo svete

\begin{tabular}{|l|c|c|}
\hline & \multicolumn{2}{|c|}{$\begin{array}{c}\text { Uplatňovanie ekonomickej regulácie } \\
\text { letiskových poplatkov }\end{array}$} \\
\hline Krajina & ÁNO & NIE \\
\hline Austrália & $\checkmark$ & \\
\hline Belgicko & $\checkmark$ & $\checkmark$ \\
\hline Cyprus & & $\checkmark$ \\
\hline Česká republika & & \\
\hline Dánsko & $\checkmark$ & \\
\hline Estónsko & $\checkmark$ & \\
\hline
\end{tabular}

\footnotetext{
* Mgr. Ing. Alena Novák sedláčková, Žilisnká univerzita v Žiline, Univerzitná 1, 01026 Žilina tel.: +421 41513 3451, fax: +421 415131517

e-mail: Alena.Sedlackova@fpedas.uniza.sk

${ }^{1}$ Starkie,D.:Airport Regulation and competition, Elsevier Science, 2002

${ }^{2}$ Drabbe, H.: EC Competition Policy in Relation to Airports, Torino, 1999
} 


\begin{tabular}{|l|c|c|}
\hline Fínsko & & $\checkmark$ \\
\hline Francúzsko & $\checkmark$ & $\checkmark$ \\
\hline Grécko & & \\
\hline Holandsko & $\checkmark$ & $\checkmark$ \\
\hline Írsko & & $\checkmark$ \\
\hline Litva & & \\
\hline Lotyšsko & $\checkmark$ & \\
\hline Luxembursko & $\checkmark$ & \\
\hline Mad'arsko & $\checkmark$ & \\
\hline Malta & $\checkmark$ & \\
\hline Nemecko & $\checkmark$ & $\checkmark$ \\
\hline Nový Zéland & $\checkmark$ & \\
\hline Nórsko & & \\
\hline Pol'sko & $\checkmark$ & \\
\hline Portugalsko & $\checkmark$ & \\
\hline Rakúsko & & \\
\hline Slovenská republika & & \\
\hline Slovinsko & $\checkmark$ & $\checkmark$ \\
\hline Španielsko & $\checkmark$ & \\
\hline Švajčiarsko & & \\
\hline Švédsko & & \\
\hline Taliansko & & \\
\hline Vel'ká Británia & & \\
\hline Zdroj: spracované autorkou práce na základe zdrojov ${ }^{3}$ & \\
\hline
\end{tabular}

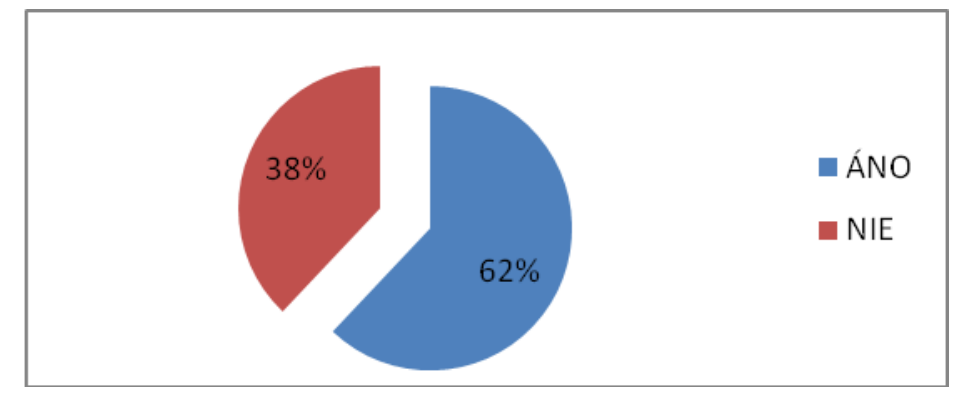

Graf 1 :Uplatňovanie ekonomickej regulácie letiskových poplatkov v Európe a vo svete

\footnotetext{
${ }^{3}$ NERA Economic Consulting:The EU Directive on Airport Charges: Principles, Current Situation, and Developments.20.1.2009, www.nera.com MARQUES,R.C.,BROCHADO, A.:Airport regulation in Europe: Is there need for a European Observatory? Transport Policy 15(2008), Elsevier Ltd.,2008, str. 163-172

NIEMEIER,H.M.:Regulation of Large Airports: Status Quo and Option for Reform.Joint Transport Research CentreDiscussion Paper 2009-10, OECD, International Transport Forum,2009

MUELLER,J.: Project GAP-Regulation Summary. G.A.R.S., Germany, Berlin, 2009

- $\quad$ s týmito zdrojmi autorka pracuje aj v nasledujúcich tabul'kách
} 


\section{Modely, mechanizmy a rozsah uplatňovania ekonomickej regulácie letísk}

Modely a formuly prístupu k ekonomickej regulácii letiskových poplatkov v Európe vznikali na princípe základných regulačných mechanizmov a spôsobov rozsahu ich uplatňovania, ako aj s ohl'adom na konkrétne socioekonomické aspekty oblastí a regiónov, kde sú vybrané letiská situované.

Štáty si do všeobecne známych a uplatňovaných regulačných formúl vkladajú rôzne alternatívne ukazovatele, ktoré charakterizujú podmienky práve na ich letisku a vytvárajú si tak svoje vlastné modely, ktoré aplikujú pri ekonomickej regulácii letísk vich krajine a zohl'adňujú tak nie len potrebnost', či nepotrebnost' ekonomickej regulácie letiskových poplatkov, ale aj politicko-ekonomicko-sociálno-geografické faktory, ktoré pri ekonomickej regulácii letísk nesmú byt' opomenuté. Na základe toho si vytvárajú formulu regulačného mechanizmu, ktorá je vždy sui generis.

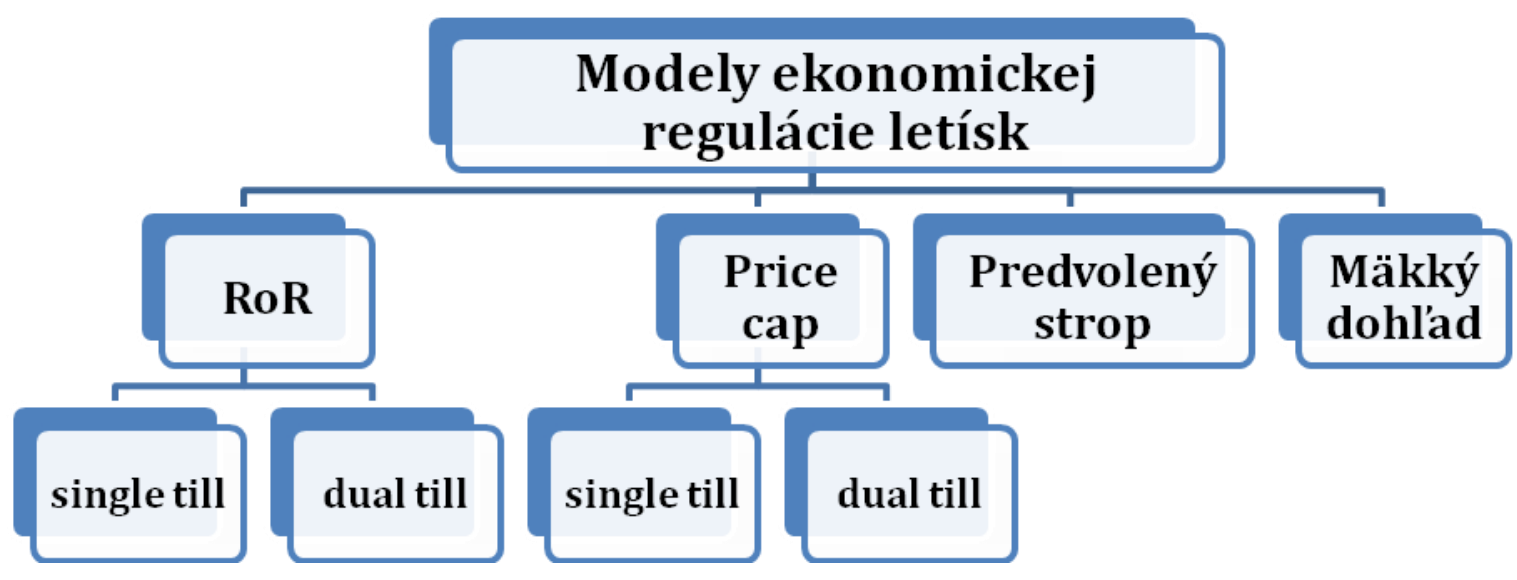

Zdroj: autorka

Graf 2: Schémy alternatívnych prístupov k regulačným mechanizmom a spôsob a rozsah ich uplatňovania pri ekonomickej regulácii letísk

Najčastejšie používaným regulačným mechanizmom je price cap (regulácia na základe cenového stropu). Tento mechanizmus má dve základné modifikácie podl'a rozsahu uplatnenia ekonomickej regulácie na výnosy letiska a to single till a dual till.

Najznámejšími reprezentantmi modelu price cap single till sú írske Letisko Dublin, britské London Heathrow, London Stanstead, London Luton, Manchester a francúzske Paris Charles de Gaulle, Paris Orly.

Tabul'ka 2: Ekonomická regulácia letiskových poplatkov regulačným mechanizmom price cap v rozsahu single till

\begin{tabular}{|l|l|l|}
\hline \multicolumn{2}{|c|}{ Price cap single till } \\
\hline Krajina & Letisko & $\begin{array}{l}\text { Cyklus } \\
\text { (rokov) }\end{array}$ \\
\hline Írsko & Dublin & 4 \\
\hline Francúzsko & Paris Charles de Gaulle & 5 \\
\hline & Paris Orly & 5 \\
\hline Nemecko & Düsseldorf & \\
\hline
\end{tabular}




\begin{tabular}{|l|l|l|}
\hline Švédsko & Stokholm & \\
\hline & Malmö & \\
\hline Vel'ká Británia & London Heathrow & 5 \\
\hline & London Stanstead & 5 \\
\hline & London Gatwick & 5 \\
\hline & Manchester & 5 \\
\hline Zdroj: autorka
\end{tabular}

Reprezentantom druhého modelu price cap dual till je dánske letisko Kodaň. Letiská v Nemecku ako Hamburg a Frankfurt tiež pristúpili na aplikáciu tohto modelu, uprednostnili ju pred spôsobom single till. Pôvodne boli týmto modelom regulované aj letiská v Austrálii, ale neskôr prešli na single till a nakoniec zmenili aj regulačný mechanizmus na dohl'ad s mäkkou rukou.

Tabul'ka 3: Ekonomická regulácia letiskových poplatkov regulačným mechanizmom price cap v rozsahu dual till

\begin{tabular}{|l|l|c|}
\hline \multicolumn{3}{|c|}{ Price cap dual till } \\
\hline Krajina & Letisko & Cyklus (rokov) \\
\hline Dánsko & Kodaň & 3 \\
\hline Nemecko & Hamburg & 5 \\
\hline & Frankfurt & 5 \\
\hline & Hannover & 5 \\
\hline Rakúsko & Viedeň & n.a. \\
\hline Malta & Malta International & 5 \\
\hline Zdroj: autorka
\end{tabular}

No sú aj letiská, ktoré využívajú mechanizmus price cap alebo RoR, ale čo do rozsahu uplatnenia regulačného mechanizmu, neaplikujú ani single till, ani dual till, ale takzvaný hybridný model, kde do regulačnej formuly sa počíta $50 \%$ z komerčných výnosov letísk.

Tabul'ka 4: Hybridný model v spôsobe uplatňovania regulačného mechanizmu

\begin{tabular}{|l|l|l|c|}
\hline Krajina & Letisko & Price cap & RRoR \\
\hline Mad'arko & Budapešt' & $\checkmark$ & \\
\hline & Ferihegy & $\checkmark$ & \\
\hline Taliansko & Rím Fiumicino & & $\checkmark$ \\
\hline & Miláno & & $\checkmark$ \\
\hline
\end{tabular}

Na základe vyššie uvedenej schémy aj regulačný mechanizmu RoR (na základe miery návratnosti) je aplikovaný do praxe v rozsahu single till ako aj dual till.

Španielske letiská Madrid, Barcelona a Palma de Mallorca, ako aj nemecké letiská Mníchov a Berlín sú regulované RoR single till. 
Tabul'ka 5: Ekonomická regulácia letiskových poplatkov regulačným mechanizmom na základe miery návratnosti v rozsahu single till

\begin{tabular}{|l|l|}
\hline \multicolumn{2}{|l|}{ Regulácia na základe miery návratnosti v rozsahu single till } \\
\hline Krajina & Letisko \\
\hline Nemecko & Berlín \\
\hline & Mníchov \\
\hline Portugalsko & Lisabon \\
\hline & Porto \\
\hline & Faro \\
\hline Španielsko & Madrid \\
\hline & Barcelona \\
\hline & Palma de Mallorca \\
\hline Belgicko & Brusel \\
\hline Nórsko & Oslo \\
\hline Zdroj: autorka &
\end{tabular}

Regulačný model na základe miery návratnosti $\mathrm{v}$ rozsahu dual till sa uplatňuje na holandskom letisku Schiphol Amsterdam.

Regulačný mechanizmus RoR bez udania rozsahu uplatňovania tohto mechanizmu na výnosy majú v Estónsku na letisku Tallin-Ulemiste, ale aj v Luxembursku na ich jedinom letisku.

Regulačný mechanizmus „light handed“ (tzv. regulácia pohotovostná alebo s mäkkým dohl’adom) je aplikovaný na letiskách v Austrálii a Novom Zélande.

Pri ekonomickej regulácii letísk nie je dôležitý iba mechanizmus ekonomickej regulácie letiskových poplatkov a ich spôsob a rozsah uplatňovania, ale aj postavenie regulátora. Dôležité je aj, či prebiehajú nezávislé konzultácie medzi užívatel'mi, záujmovými skupinami, nezávislými alebo závislými regulátormi a komisiami, ktoré majú na starosti ochranu hospodárskej sút’aže. V nasledujúce tabul'ke uvádzam ustanovených regulátorov a záujmové skupiny medzi ktorými dochádza ku konzultáciám počas regulačného procesu.

Tabul'ka 6: Krajiny, letiská, postavenie regulátorov a konzultačné procesy

\begin{tabular}{|c|c|c|c|c|c|}
\hline Krajina & Letisko & $\begin{array}{l}\text { Nezávislý } \\
\text { regulátor }\end{array}$ & $\begin{array}{l}\text { Závislý } \\
\text { regulátor }\end{array}$ & $\begin{array}{l}\text { Národní } \\
\text { regulátori }\end{array}$ & $\begin{array}{l}\text { Nezávislé } \\
\text { konzultácie } \\
\text { užívatel'ov s: }\end{array}$ \\
\hline Belgicko & Brusel & & $\checkmark$ & $\begin{array}{l}\text { Ministerstvo } \\
\text { dopravy }\end{array}$ & $\begin{array}{l}\text { IATA, Letecký } \\
\text { úrad }\end{array}$ \\
\hline Dánsko & Kodaň & & $\checkmark$ & Letecký úrad & $\begin{array}{l}\text { letecké } \\
\text { spoločnosti } \\
\text { a ich zákazníci }\end{array}$ \\
\hline \multirow[t]{2}{*}{ Francúzsko } & $\begin{array}{l}\text { Paris Charles de } \\
\text { Gaulle }\end{array}$ & & $\checkmark$ & & \\
\hline & Paris Orly & & $\checkmark$ & vláda & \\
\hline Holandsko & Amsterdam & $\checkmark$ & & Úrad na & (neskoršie \\
\hline
\end{tabular}




\begin{tabular}{|c|c|c|c|c|c|}
\hline & Schiphol & $\checkmark$ & & $\begin{array}{l}\text { ochranu } \\
\text { hospodárskej } \\
\text { sút'aže }\end{array}$ & $\begin{array}{l}\text { prešetrenie } \\
\text { možné) }\end{array}$ \\
\hline Írsko & Dublin & $\checkmark$ & & $\begin{array}{l}\text { Komisia pre } \\
\text { reguláciu } \\
\text { civilného } \\
\text { letectva } \\
\end{array}$ & $\begin{array}{l}\text { záujmové } \\
\text { skupiny,zákon } \\
\text { ný odvolací } \\
\text { výbor } \\
\end{array}$ \\
\hline \multirow[t]{2}{*}{ Mad'arsko } & Budapešt’ & & $\checkmark$ & \multirow{2}{*}{$\begin{array}{l}\text { Ministerstvo } \\
\text { hospodárstva a } \\
\text { dopravy }\end{array}$} & \multirow[b]{2}{*}{ Letecký úrad } \\
\hline & Ferihegy & & $\checkmark$ & & \\
\hline Malta & $\begin{array}{l}\text { Malta } \\
\text { International }\end{array}$ & & & $\begin{array}{l}\text { Rada civilného } \\
\text { letectva, } \\
\text { Ministerstvo na } \\
\text { ochranu } \\
\text { hospodárskej } \\
\text { sút'aže }\end{array}$ & $\begin{array}{l}\text { (neskoršie } \\
\text { prešetrenie } \\
\text { možné) }\end{array}$ \\
\hline \multirow[t]{5}{*}{ Nemecko } & Hamburg & & $\checkmark$ & \multirow{5}{*}{$\begin{array}{l}\text { Federálne } \\
\text { ministerstvo } \\
\text { dopravy }\end{array}$} & \multirow{5}{*}{$\begin{array}{l}\text { prebiehajú } \\
\text { rozšírené } \\
\text { konzultácie s } \\
\text { užívatel'mi }\end{array}$} \\
\hline & Frankfurkt & & $\checkmark$ & & \\
\hline & Düsseldorf & & $\checkmark$ & & \\
\hline & Berlin & & $\checkmark$ & & \\
\hline & Mníchov & & $\checkmark$ & & \\
\hline Nórsko & Oslo & & $\checkmark$ & $\begin{array}{l}\text { Letecký úrad } \\
\text { menovaný } \\
\text { Ministerstvom } \\
\text { dopravy }\end{array}$ & $\begin{array}{l}\text { Ministerstvo } \\
\text { dopravy, } \\
\text { Letecký úrad }\end{array}$ \\
\hline \multirow[t]{3}{*}{ Portugalsko } & Lisabon & $\checkmark$ & & \multirow[b]{3}{*}{$\begin{array}{l}\text { Národný } \\
\text { inštitút pre } \\
\text { civilné } \\
\text { letectvo, } \\
\text { Ministerstvo } \\
\text { verejných vecí, } \\
\text { dopravy }\end{array}$} & \multirow{3}{*}{$\begin{array}{l}\text { Komisia } \\
\text { užívatel'ov } \\
\text { letísk, } \\
\text { letiskový } \\
\text { prevádzkovate } \\
\text { l'ANA, } \\
\text { Národný } \\
\text { inštitút pre } \\
\text { civilné letectvo }\end{array}$} \\
\hline & Porto & $\checkmark$ & & & \\
\hline & Faro & $\checkmark$ & & & \\
\hline Rakúsko & Viedeň & $\checkmark$ & & Letecký úrad & $\begin{array}{l}\text { IATA, Letecký } \\
\text { úrad }\end{array}$ \\
\hline \multirow[t]{3}{*}{ Španielsko } & Madrid & & $\checkmark$ & \multirow{3}{*}{$\begin{array}{l}\text { Generálne } \\
\text { riaditel'stvo } \\
\text { civilného } \\
\text { letectva, } \\
\text { Generálny } \\
\text { sekretariát } \\
\text { dopravy, } \\
\text { Ministerstvo } \\
\text { rozvoja }\end{array}$} & \multirow[b]{3}{*}{$\begin{array}{l}\text { letecké } \\
\text { spoločnosti, } \\
\text { parlament } \\
\text {,súdy(na } \\
\text { overenie) }\end{array}$} \\
\hline & Barcelona & & $\checkmark$ & & \\
\hline & Palma de Mallorca & & $\checkmark$ & & \\
\hline \multirow[t]{2}{*}{ Švédsko } & Malmö & & & \multirow[b]{2}{*}{ Letecký úrad } & \multirow[b]{2}{*}{ nie } \\
\hline & Štokholm & & & & \\
\hline Taliansko & Miláno & & $\checkmark$ & Letecký úrad & Komisia \\
\hline
\end{tabular}




\begin{tabular}{|c|c|c|c|c|c|}
\hline & Roma Fiumicino & & $\checkmark$ & & užívatel'ov \\
\hline $\begin{array}{l}\text { Vel'ká } \\
\text { Británia }\end{array}$ & London Heathrow & $\checkmark$ & & & \multirow{4}{*}{$\begin{array}{l}\text { letecké } \\
\text { spoločnosti, } \\
\text { letiská, } \\
\text { Letecký úrad } \\
\text { Komisia pre } \\
\text { hospodársku } \\
\text { sút’až }\end{array}$} \\
\hline & London Gatwick & $\checkmark$ & & & \\
\hline & London Stanstad & $\checkmark$ & & & \\
\hline & Manchester & $\checkmark$ & & Letecký úrad & \\
\hline
\end{tabular}

Zdroj: autorka

\section{Záver}

$\mathrm{Na}$ základe vyššie uvedených tabuliek je dôležité si uvedomit' rôznorodost' $\mathrm{v}$ prístupoch $\mathrm{k}$ ekonomickej regulácii letísk. Tieto prístupy sú odlišné na základe kontinentov, štátov, ale aj v rámci jedného štátu. Pokial' je v niektorom z vybraných štátov uplatňovaná ekonomická regulácia letiskových poplatkov neznamená to vždy, že všetky letiská danej krajiny uplatňujú rovnaký model, niekedy ani nie všetky sú regulované a to na základe ich postavenia (či sú letiskom s vnútroštátnou, medzinárodnou alebo medzikontinentálnou prepravou), lokalizácie v krajine a na základe počtu prepravených cestujúcich a tovaru. Poukázat' na takúto situáciu môžeme vo Vel'kej Británii, kde s ekonomickou reguláciou letiskových poplatkov začali na vybraných štyroch letiskách a na všetkých uplatnili rovnaký regulačný model aj ked' formula nie je úplne identická (rozdiel v X faktore). Na druhej strane sú štáty, kde sa začalo s reguláciou, ale letiská neuplatňujú rovnaké regulačné modely ako napr. Nemecko. Dôležité je nezabudnút' aj na krajiny ako Rakúsko, kde zo všetkých letísk podlieha regulačnému mechanizmu iba jedno a to Viedeň.

Obdobnú situáciu konštatujeme aj pri pohl’ade na regulátorov, ktorých poslanie je vždy rovnaké, ale niekedy nespíňajú ani základné v poslednej dobe najviac zdôrazňované nezávislé postavenie. Regulátori majú byt' nezávislí ako od prevádzkovatel'ov letiska, tak aj od užívatel'ov. Ale ako dosiahnut' túto situáciu, pokial' je regulátorom vládny orgán a majoritným vlastníkom regulovaného subjektu (letiska) je štát?

\section{Literatúra}

[1] STARKIE, D.:Airport Regulation and competition, Elsevier Science, 2002

[2] DRABBE, H.: EC Competition Policy in Relation to Airports, Torino, 1999

[3] NERA Economic Consulting:The EU Directive on Airport Charges: Principles, Current

Situation, and Developments.20.1.2009, www.nera.com

[4] MARQUES,R.C.,BROCHADO, A.:Airport regulation in Europe: Is there need for

a European Observatory?Transport Policy 15(2008), Elsevier Ltd.,2008

[5] NIEMEIER,H.M.:Regulation of Large Airports: Status Quo and Option for Reform.Joint Transport Research Centre-Discussion Paper 2009-10 , OECD, International Transport Forum,2009

[6] MUELLER,J.: Project GAP-Regulation Summary. G.A.R.S., Germany, Berlin, 2009

\section{Grantová podpora}

Článok je publikovaný v rámci riešenia projektu VEGA 1/0274/08 - „Základný výskum zvyšovania bezpečnosti a kvality v civilnom letectve“، 